Article

\title{
Novel Boronate Probe Based on 3-Benzothiazol-2-yl-7-hydroxy- chromen-2-one for the Detection of Peroxynitrite and Hypochlorite
}

\author{
Julia Modrzejewska ${ }^{1}$, Marcin Szala ${ }^{1}{ }^{(0)}$, Aleksandra Grzelakowska ${ }^{1}$, Małgorzata Zakłos-Szyda ${ }^{2}{ }^{(D}$, \\ Jacek Zielonka ${ }^{3, *}$ and Radosław Podsiadły ${ }^{1, *(D)}$ \\ 1 Institute of Polymer and Dye Technology, Faculty of Chemistry, Lodz University of Technology, \\ Stefanowskiego 12/16, 90-924 Lodz, Poland; julia.modrzejewska@dokt.p.lodz.pl (J.M.); \\ marcin.szala@p.lodz.pl (M.S.); aleksandra.grzelakowska@p.lodz.pl (A.G.) \\ 2 Institute of Molecular and Industrial Biotechnology, Faculty of Biotechnology and Food Sciences, Lodz \\ University of Technology, Stefanowskiego 2/22, 90-537 Lodz, Poland; malgorzata.zaklos-szyda@p.lodz.pl \\ 3 Department of Biophysics, Medical College of Wisconsin, 8701 Watertown Plank Road, \\ Milwaukee, WI 53226, USA \\ * Correspondence: jzielonk@mcw.edu (J.Z.); radoslaw.podsiadly@p.lodz.pl (R.P.); \\ Tel.: +1-(414)-955-4789 (J.Z.); +48-42-631-32-31 (R.P.)
}

check for updates

Citation: Modrzejewska, J.; Szala, M.; Grzelakowska, A.; Zakłos-Szyda, M.; Zielonka, J.; Podsiadły, R. Novel Boronate Probe Based on 3-Benzothiazol-2-yl-7-hydroxychromen-2-one for the Detection of Peroxynitrite and Hypochlorite. Molecules 2021, 26, 5940. https://doi.org/10.3390/ molecules26195940

Academic Editor: Peter Verwilst

Received: 30 August 2021

Accepted: 24 September 2021

Published: 30 September 2021

Publisher's Note: MDPI stays neutral with regard to jurisdictional claims in published maps and institutional affiliations.

Copyright: (c) 2021 by the authors. Licensee MDPI, Basel, Switzerland. This article is an open access article distributed under the terms and conditions of the Creative Commons Attribution (CC BY) license (https:// creativecommons.org/licenses/by/ $4.0 /)$.
Abstract: Derivatives of coumarin, containing oxidant-sensitive boronate group, were recently developed for fluorescent detection of inflammatory oxidants. Here, we report the synthesis and the characterization of 3-(2-benzothiazolyl)-7-coumarin boronic acid pinacol ester (BC-BE) as a fluorescent probe for the detection of peroxynitrite $\left(\mathrm{ONOO}^{-}\right)$, with high stability and a fast response time. The BC-BE probe hydrolyzes in phosphate buffer to 3-(2-benzothiazolyl)-7-coumarin boronic acid (BC-BA) which is stable in the solution even after a prolonged incubation time $(24 \mathrm{~h})$. BC-BA is slowly oxidized by $\mathrm{H}_{2} \mathrm{O}_{2}$ to form the phenolic product, 3-benzothiazol-2-yl-7-hydroxy-chromen2-one (BC-OH). On the other hand, the $\mathbf{B C}-\mathbf{B A}$ probe reacts rapidly with $\mathrm{ONOO}^{-}$. The ability of the $\mathbf{B C}-\mathbf{B A}$ probe to detect $\mathrm{ONOO}^{-}$was measured using both authentic $\mathrm{ONOO}^{-}$and the system cogenerating steady-state fluxes of $\mathrm{O}_{2}{ }^{\bullet-}$ and ${ }^{\bullet} \mathrm{NO}$. BC-BA is oxidized by $\mathrm{ONOO}^{-}$to $\mathbf{B C}-\mathbf{O H}$. However, in this reaction 3-benzothiazol-2-yl-chromen-2-one (BC-H) is formed in the minor pathway, as a peroxynitrite-specific product. BC-OH is also formed in the reaction of $\mathbf{B C}-\mathbf{B A}$ with $\mathrm{HOCl}$, and subsequent reaction of $\mathbf{B C}-\mathbf{O H}$ with $\mathrm{HOCl}$ leads to the formation of a chlorinated phenolic product, which could be used as a specific product for $\mathrm{HOCl}$. We conclude that BC-BA shows potential as an improved fluorescent probe for the detection of peroxynitrite and hypochlorite in biological settings. Complementation of the fluorescence measurements by HPLC-based identification of oxidant-specific products will help to identify the oxidants detected.

Keywords: fluorescent probe; coumarin derivatives; peroxynitrite

\section{Introduction}

Coumarin skeleton is frequently used to construct a range of fluorescent dyes due to high fluorescent quantum yields and tunable emission wavelengths. The emission of coumarin-based fluorophores can be finely tuned by appropriate substitution in $2 \mathrm{H}$ chromen-2-one skeleton. Fluorescence can be red shifted by the placement of electrondonating groups in the six- or seven-position or electron-accepting groups in the three- or four-position of the skeleton [1].

A widely used example of coumarin dyes is C.I. Disperse Yellow 82 [2] which, in the 7position of the coumarin ring, contains the $N, N$-diethylamino group and, in the 3-position, a benzimidazole residue. Derivatives of coumarin generally show good photostability which is rather unusual among fluorescent dyes [3]. 
7-Hydroxy-2H-chromen-2-one (also known as 7-hydroxycoumarin, $\mathrm{COH}$, or umbelliferone) is widely used as a fluorophore in sensors and probes due to the relatively simple methods of masking its hydroxyl group and a high water solubility (621 $\mathrm{mg} \mathrm{L}^{-1}$ [4]). Umbelliferone was chosen as a scaffold to construct a wide variety of probes, by listing only several example, e.g., for the detection of anions [1,5,6], formaldehyde [7], hydrogen sulfide [8-10], biothiols [11,12], enzymes [13,14], Ser/Thr protein phosphatases [15], sulfane sulfurs [16], peroxynitrite [17], and hydrogen peroxide [18,19].

However, $\mathrm{COH}$ has several disadvantages, including a short wavelength UV-absorption at $320 \mathrm{~nm}$, a relatively low extinction coefficient $\left(\varepsilon=1.3 \times 10^{4} \mathrm{M}^{-1} \mathrm{~cm}^{-1}\right)$ [20], and a pH dependent fluorescence efficiency $[17,20,21]$. Therefore, especially for biomedical applications, alternative coumarin analogs with red-shifted absorption are sought [22].

The detection of reactive oxygen and nitrogen species is becoming more important these days. An excess of reactive oxygen species (ROS) and reactive nitrogen species (RNS) are implicated in pathologies such as cancer, cardiovascular, and neurodegenerative diseases [23]. To understand how these oxidative stressors participate in cellular function it is important to detect when, where, and what kind of specific products are produced. Significant information about reactive oxidants can be obtained using high performance liquid chromatography, mass spectrometry or other analytical procedure, but only connecting these methods with fluorescence and chemiluminescence approaches provide real-time monitoring.

There are two main fluorescence and chemiluminescence strategies for ROS/RNS detection. The first one is based on aromatic compounds that undergo oxidation to a fluorescent product (redox probes) and, the second, in which compound contains masked fluorophore. These are often called "non-redox" probes, as the fluorescence of the probe is uncovered through nucleophilic attack of the reactive species on the blocking group. Boronates are most often investigated as leaving groups [24-31].

Continuing our research on the synthesis of low molecular weight boronate probes for the detection of peroxynitrite [27-29], we focused our efforts on the synthesis of a coumarin probe with the excitation band located above $400 \mathrm{~nm}$. With the exception of coumarin 7-boronic acid, CBA, so far boronate probes based on the coumarin skeleton have been obtained by the boronobenzylation process [30]. However, the oxidative conversion of boronobenzyloxycarbonyl- and boronobenzylcoumarin derivatives not only produces a fluorophore but also releases quinone methide $(\mathrm{QM})$ moiety. The self-immolation of such a moiety results in the delayed formation of a fluorescent product, while fluorophores with direct derivatization by the boronate group produce the fluorescent product instantly upon oxidation [28]. Another potential disadvantage of boronobenzylated probes arises from the fact that QM as an electrophile may influence the redox state of the cell and thus influence the redox environment studied. [31]

Here, we report the synthesis and the characterization of a novel 3-(2-benzothiazolyl)7-coumarin boronic acid pinacol ester, BC-BE, an analogue of the CBA probe with a benzothiazole residue in the 3-position of the coumarin ring (Scheme 1). In aqueous solutions containing a phosphate buffer ( $\mathrm{pH}$ 7.4), the BC-BE probe undergoes fast hydrolysis to its boronic acid (BC-BA). Oxidation of BC-BE results in instantaneous formation of 3-benzothiazol-2-yl-7-hydroxy-chromen-2-one $\mathbf{B C - O H}$, a fluorescent dye with improved photophysical properties as compared to $\mathrm{COH}$.
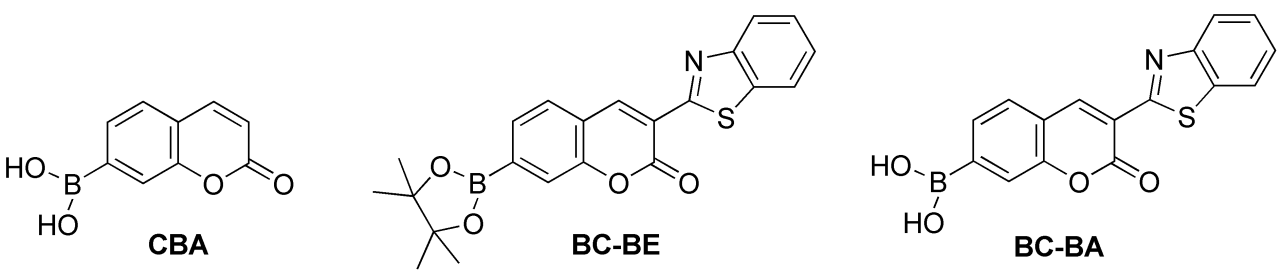

Scheme 1. Pro-coumarin boronate based probes. 


\section{Results}

\subsection{Synthesis}

The BC-BE boronate probe was obtained in a two-step protocol starting from the fluorophore BC-OH, prepared from 3-cyano-7-hydroxycoumarin (3) and ortho-aminothiophenol (4) according to the published procedure [32] (Scheme 2). In the first step, the phenolic hydroxyl group was converted into the appropriate triflate BC-OTf with a $99 \%$ yield. In the second step, BC-OTf was transformed to BC-BE in a $\mathrm{Pd}(\mathrm{dppf}) \mathrm{Cl}_{2}$-assisted reaction with bis(pinacolato)diboron. Since the probe was designed to detect peroxynitrite, the anticipated minor product, BC-H coumarin derivative was also prepared via a classical one-step condensation between appropriate ortho-hydroxybenzaldehyde (1b) and benzothiazole-2-carbonitrile (2).

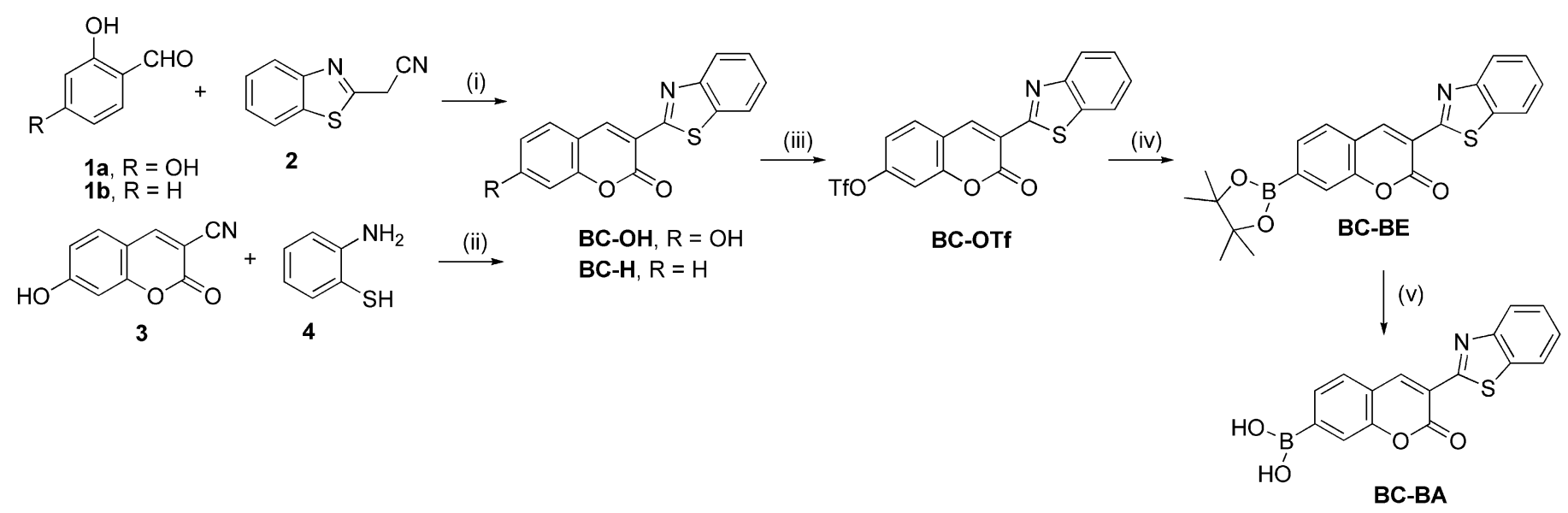

Scheme 2. Synthesis of novel boronates based on 3-benzothiazol-2-yl-7-hydroxy-chromen-2-one. Reagents and conditions: (i) 1. EtOH, piperidine, rt, $3 \mathrm{~h}$; $2.10 \% \mathrm{HCl}$, reflux, $3 \mathrm{~h}$; (ii) acetic acid, $150{ }^{\circ} \mathrm{C}, \mathrm{MW}, 40 \mathrm{~min}$; (iii) $\mathrm{PhN}\left(\mathrm{SO}_{2} \mathrm{CF}_{3}\right)_{2}, \mathrm{DCM}, \mathrm{TEA}$, reflux, 4 h; (iv) $\mathrm{Pd}(\mathrm{dppf}) \mathrm{Cl}_{2}$, dppf, $\mathrm{AcOK}, 1,4$-dioxane, $100^{\circ} \mathrm{C}, \mathrm{MW}, 45 \mathrm{~min}$; (v) phosphate buffer, $\mathrm{pH} 7.4,30 \mathrm{~min}$.

\subsection{Spectroscopic Response of $\mathbf{B C}-\mathbf{B E}$}

Introduction of the benzothiazolyl group into the coumarin skeleton has only a minor effect on the acid-base properties of the phenolic hydroxyl group. In fact, the reported pKa values of $\mathbf{C O H}$ and BC-OH are 6.89 [33] and 7.0 [34], respectively. Photophysical properties of the novel boronate probe and the parent hydroxycoumarin $\mathbf{B C}-\mathbf{O H}$, as well as $\mathbf{C O H}$ are compared in Table 1. Figure 1 shows absorption and emission spectra of BC-BA, BC-H and BC-OH. Presented data demonstrate that boronate group significantly reduces the emission of the $\mathbf{B C}-\mathbf{O H}$ coumarin. $\mathbf{B C}-\mathbf{B A}$ exhibited a maximal UV-absorption at $371 \mathrm{~nm}\left(\varepsilon=25,500 \mathrm{M}^{-1} \mathrm{~cm}^{-1}\right)$ and a maximal emission at $473 \mathrm{~nm}(\Phi=0.17)$. BC-OH has absorption and emission bands red shifted in comparison with BC-BA. More importantly, this dye has a higher quantum yield of emission than BC-BA and a higher extinction coefficient (resulting in higher brightness) than $\mathrm{COH}$. Bolus addition of peroxynitrite to the solution of the BC-BA probe red shifts the absorption band (Figure 1c) and turns on fluorescence (Figure 1d). 
Table 1. Photophysical properties of studied compounds.

\begin{tabular}{|c|c|c|c|c|c|c|c|c|}
\hline & Solvent & $\begin{array}{l}\lambda_{\max } \\
{[\mathrm{nm}]}\end{array}$ & {$\left[\begin{array}{c}\mathcal{E} \\
{\left[10^{4} \mathrm{M}^{-1} \mathrm{~cm}^{-1}\right]}\end{array}\right.$} & $\begin{array}{c}\lambda_{\mathrm{ex}} \\
{[\mathrm{nm}]}\end{array}$ & $\begin{array}{c}\lambda_{\mathrm{em}} \\
{[\mathrm{nm}]}\end{array}$ & $\begin{array}{l}\text { Stokes Shift } \\
{[\mathrm{nm}]}\end{array}$ & $\Phi_{\mathrm{em}}$ & $\tau[\mathrm{ns}]^{5}$ \\
\hline \multirow{2}{*}{$\mathrm{COH}$} & $\mathrm{EtOH}$ & 326 & 1.22 & 326 & 391 & 65 & 0.10 & \\
\hline & $\mathrm{H}_{2} \mathrm{O}^{1}$ & 323 & 1.27 & 323 & 452 & 129 & $0.80^{3}(0.76)^{4}$ & \\
\hline \multirow[b]{2}{*}{ BC-OH } & $\mathrm{EtOH}$ & 396 & 3.30 & 396 & 467 & 71 & $0.70^{3}$ & 3.07 \\
\hline & EtOH:PB ${ }^{2}$ & 442 & 3.81 & 442 & 488 & 46 & $0.85^{3}$ & 3.32 \\
\hline \multirow{2}{*}{ BC-H } & $\mathrm{EtOH}$ & 364 & 2.36 & 364 & 464 & 100 & $0.14^{3}$ & 1.00 \\
\hline & EtOH:PB ${ }^{2}$ & 365 & 2.72 & 365 & 470 & 105 & $0.09^{3}$ & 1.63 \\
\hline \multirow{2}{*}{ BC-BA } & $\mathrm{EtOH}$ & 369 & 2.22 & 369 & 464 & 95 & $0.21^{3}$ & 2.60 \\
\hline & EtOH:PB ${ }^{2}$ & 371 & 2.55 & 371 & 473 & 102 & $0.17^{3}$ & 1.33 \\
\hline
\end{tabular}

${ }^{1}$ In $\mathrm{H}_{2} \mathrm{O}$ (pH 7.2) [20], ${ }^{2}$ Aqueous phosphate buffer (100 mM, pH 7.4):EtOH (4:1), ${ }^{3}$ According to quinine sulfate ( $\Phi_{\text {ref }} 0.54$ in water) [21], ${ }^{4} \mathrm{NaHCO}_{3}-\mathrm{NaOH}$ buffer (10 mM, pH 10.0, containing 1\% EtOH) [35], ${ }^{5}$ Fluorescence lifetime was determined by TCSPC single photon counting using FL900 spectrofluorometer(Edinburgh Instruments, Livingston, UK).

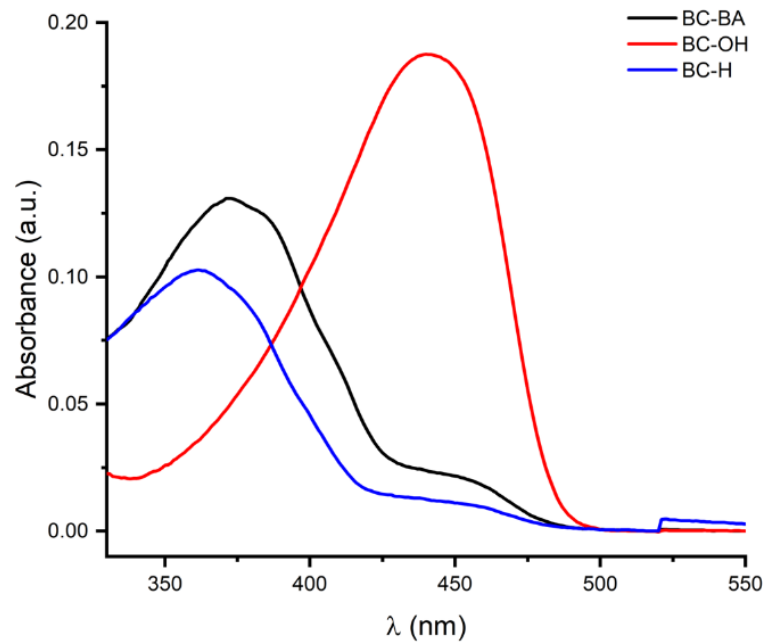

(a)

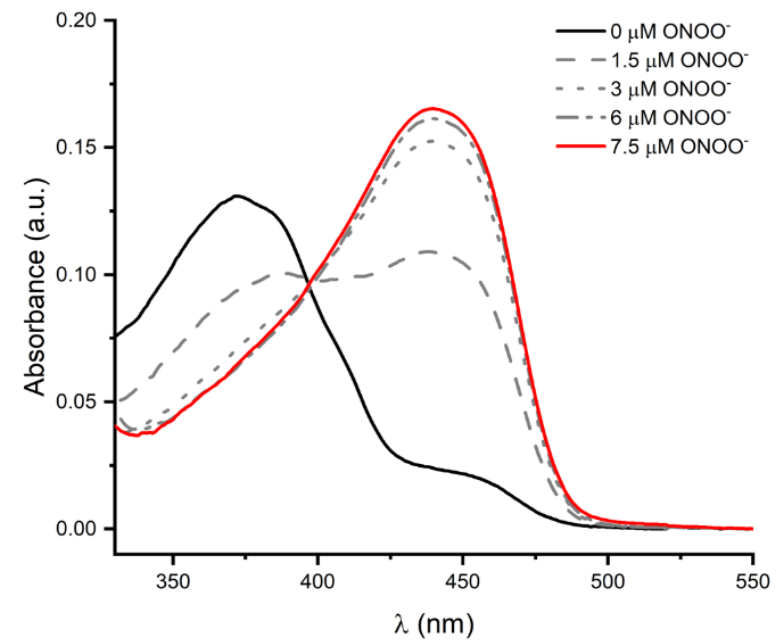

(c)

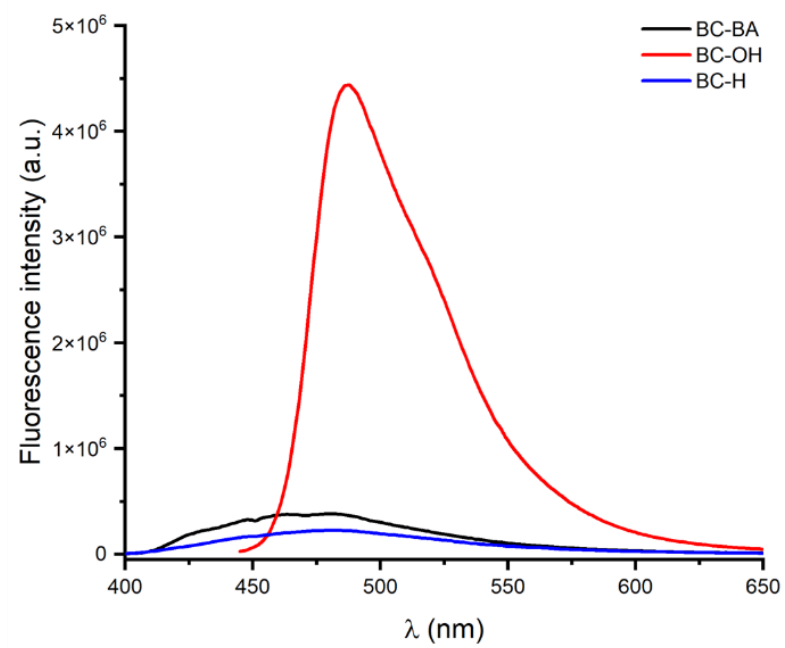

(b)

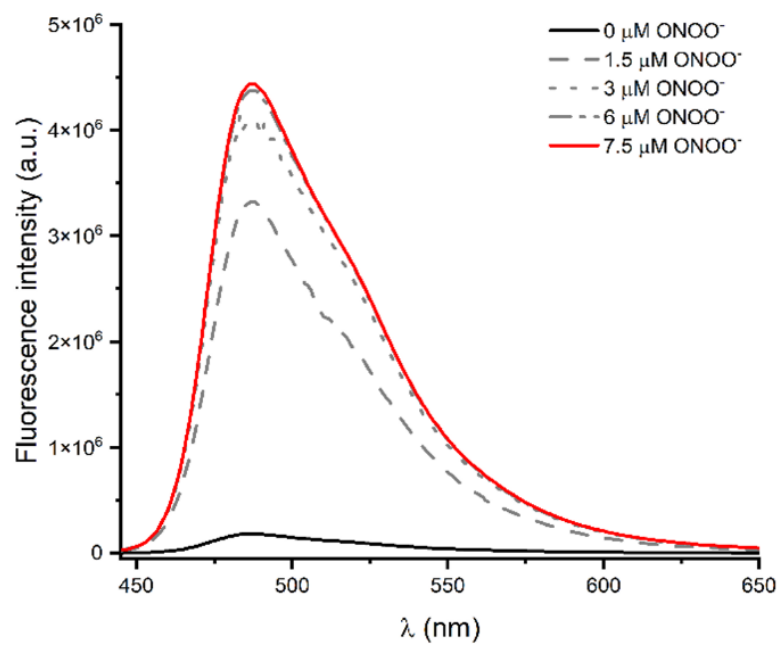

(d)

Figure 1. Absorption and emission spectra of studied coumarins recorded in mixture of phosphate buffer (0.1 M, pH 7.4) and EtOH (10\%). (a) Absorption spectra of BC-OH, BC-BA, and BC-H (5 $\mu \mathrm{M}$ each); (b) fluorescence spectra of BC-OH, BC-BA, and $\mathbf{B C}-\mathbf{H}\left(5 \mu \mathrm{M}\right.$ each, $\left.\lambda_{\mathrm{ex}}=\lambda_{\max }\right)$; (c) absorption spectra of $\mathbf{B C}-\mathbf{B A}$ probe $(5 \mu \mathrm{M})$ recorded before and after bolus addition of different amount of peroxynitrite $(0,1.5,4.5,6,7.5 \mu \mathrm{M}) ;(\mathbf{d})$ emission spectra of the BC-BA probe $\left(5 \mu \mathrm{M}, \lambda_{\mathrm{ex}}=442 \mathrm{~nm}\right)$ recorded before and after bolus addition of different amount of peroxynitrite $(0,1.5,4.5,6,7.5 \mu \mathrm{M})$. 


\subsection{Reactivity towards Biological Oxidants}

The effectiveness of the BC-BA probe for the detection of peroxynitrite was also measured using the system co-generating steady fluxes of $\mathrm{O}_{2}{ }^{\bullet-}$ (from hypoxanthine (HX) and xanthine oxidase $\mathrm{XO}$ ) and ${ }^{\bullet} \mathrm{NO}$ (from spermine-NONOate). The profile of the $\mathbf{B C}-\mathbf{B A}$ probe oxidation as a measure of $\mathrm{ONOO}^{-}$formation in a matrix of various fluxes of $\mathrm{O}_{2}{ }^{\bullet-}$ and ${ }^{\bullet} \mathrm{NO}$ is shown in Figure 2a.
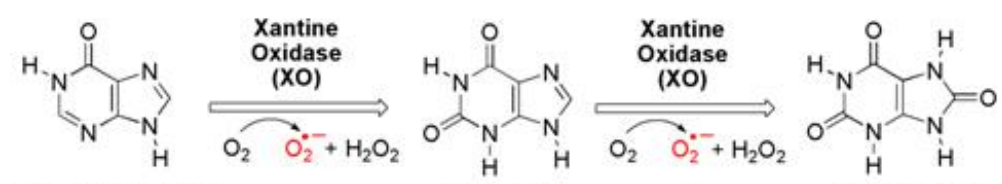

Hypoxantine (HX

Xantine (X)

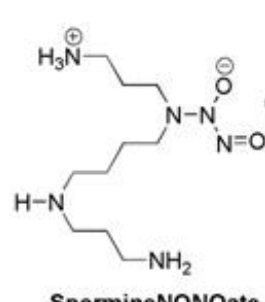

SpermineNONOate

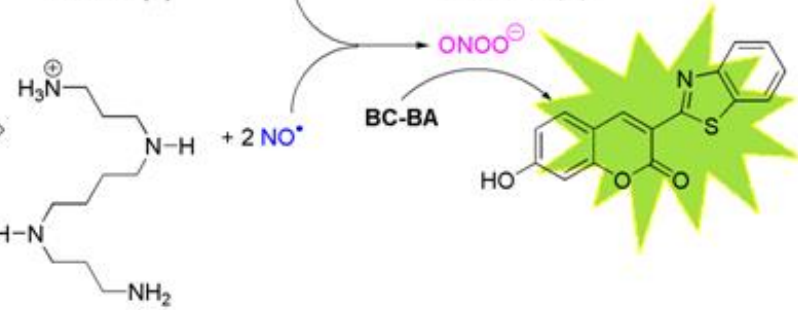

(a)

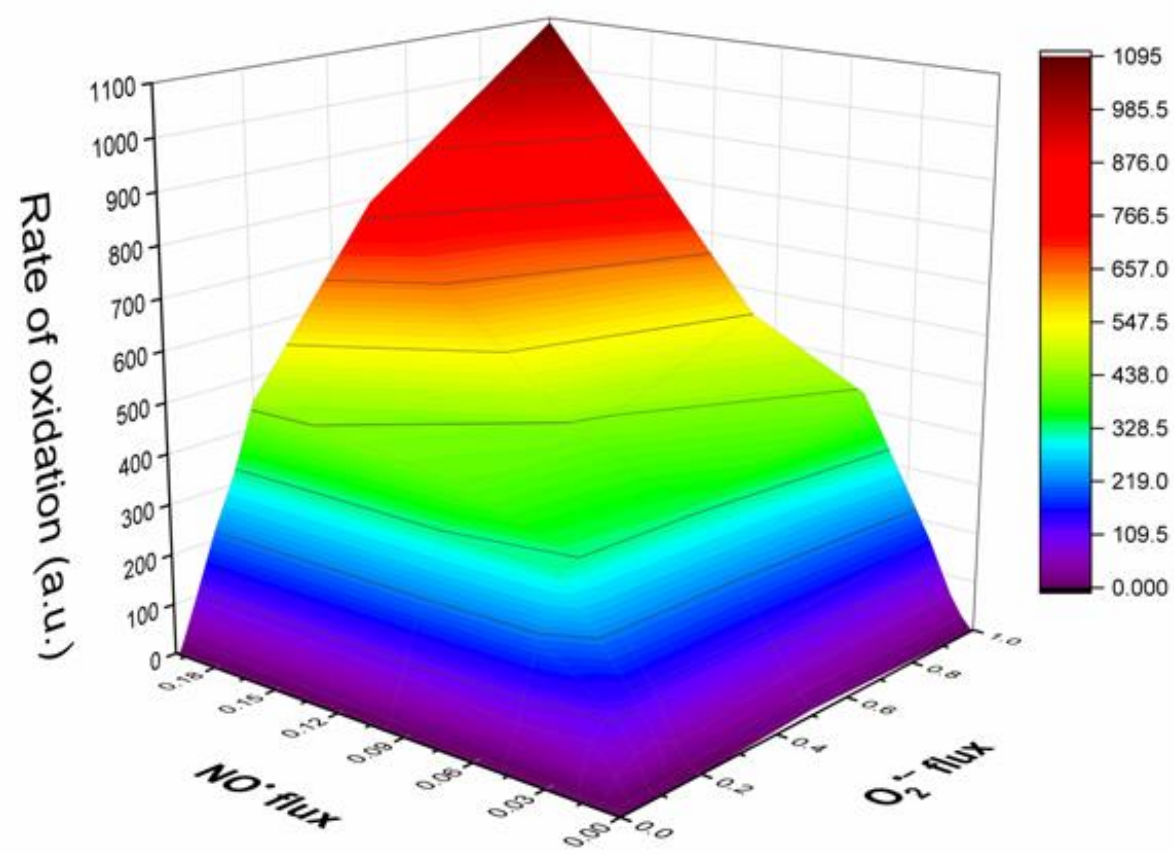

(b)

Figure 2. Measurement of peroxynitrite formation in situ by monitoring oxidation of BC-BA $(20 \mu \mathrm{M})$ using a 96-well fluorescence plate reader. (a) The formation of $\mathrm{O}_{2}{ }^{\bullet-}$ from incubations containing hypoxanthine $\mathrm{HX}(100 \mu \mathrm{M})$ and xanthine oxidase $\mathrm{XO}(0-0.4$ milliunits $/ \mathrm{mL})$ in a phosphate buffer (pH 7.4; $50 \mathrm{mM})$ containing DTPA $(100 \mu \mathrm{M})$, and $\bullet$ NO generation from a thermal decomposition of spermine-NONOate $(0-50 \mu \mathrm{M})$. Peroxynitrite, formed from co-generated fluxes of $\mathrm{O}_{2}{ }^{\bullet-}$ and $\bullet \mathrm{NO}$, oxidizes BC-BA to fluorescent $\mathbf{B C}-\mathbf{O H}$; (b) the rate of increase fluorescence intensity during the oxidation of the $\mathbf{B C}-\mathbf{B A}$ probe in the presence of varying fluxes of $\mathrm{O}_{2}{ }^{\bullet-}$ and ${ }^{\bullet} \mathrm{NO}$ in the phosphate buffer (pH 7.4, $50 \mathrm{mM})$ with DTPA $(100 \mu \mathrm{M}), \mathrm{HX} / \mathrm{XO}$, spermine-NONOate, and CAT $(100 \mathrm{U} / \mathrm{mL})$. The fluorescence intensity $\left(\lambda_{\text {ex }}\right.$ at $405 \mathrm{~nm}, \lambda_{\text {em }}$ at $535 \mathrm{~nm}$ ) of the reaction mixtures consisting of BC-BA $(20 \mu \mathrm{M})$ and $\mathrm{HX} / \mathrm{XO}\left(\mathrm{O}_{2}{ }^{\bullet-}\right.$ flux: $\left.0-1 \mu \mathrm{M} / \mathrm{min}\right)$ and spermine-NONOate $\left({ }^{\bullet} \mathrm{NO}\right.$ flux: $\left.0-0.2 \mu \mathrm{M} / \mathrm{min}\right)$ was measured over a period of $2 \mathrm{~h}$. 
Next, we determined the stoichiometry of the reaction between BC-BA and peroxynitrite. Using HPLC, we analyzed products formed after the bolus addition of $\mathrm{ONOO}^{-}$to the phosphate buffer containing the BC-BA probe. Figure 3a shows that, after $5 \mathrm{~min}$ of incubation, we observed the formation of the $\mathbf{B C}-\mathbf{O H}$ coumarin as the main product. The formation of BC-OH can be observed with the naked eye, as shown in Figure 3c. The hue of fluorescence also changes (Figure $3 \mathrm{~d}$ ). Figure $3 \mathrm{~b}$ showed that $\mathbf{B C}-\mathbf{B A}$ reacts with $\mathrm{ONOO}^{-}$ forming the $\mathbf{B C}-\mathbf{O H}$ dye with c.a. $90 \%$ yield. These results are consistent with a previously reported reactivity of arylboronate-derived probes toward peroxynitrite [30]. Peroxynitriteinduced oxidation of boronic acid $\mathrm{Ar}-\mathrm{B}(\mathrm{OH})_{2}$ or ester $\mathrm{Ar}-\mathrm{B}(\mathrm{pin})$ proceeds via two pathways, and typically leads to the formation of minor but $\mathrm{ONOO}^{-}$-specific products $\left(\mathrm{ArNO}_{2}, \mathrm{ArH}\right)$ in addition to the major phenolic product $(\mathrm{ArOH})$. Therefore, we anticipated that the BC-BA reaction with $\mathrm{ONOO}^{-}$would produce the corresponding minor products $\left(\mathbf{B C}-\mathrm{NO}_{2}\right.$ and BC-H), as shown in Scheme 3. However, under the experimental conditions used we only detected BC-H (c.a. 9\% yield), probably due to the usage of ethanol as an organic co-solvent, which efficiently reduces the phenyl-type radical $\mathbf{B C}^{\bullet}$ to $\mathbf{B C}-\mathbf{H}$ (Scheme 2). Previously, it has shown that in the presence of phenyl radical scavengers (2-propanol), the phenyl radical formed in the radical pathway is almost quantitatively converted into the product in which the boronate moiety is replaced by a hydrogen atom $[36,37]$.

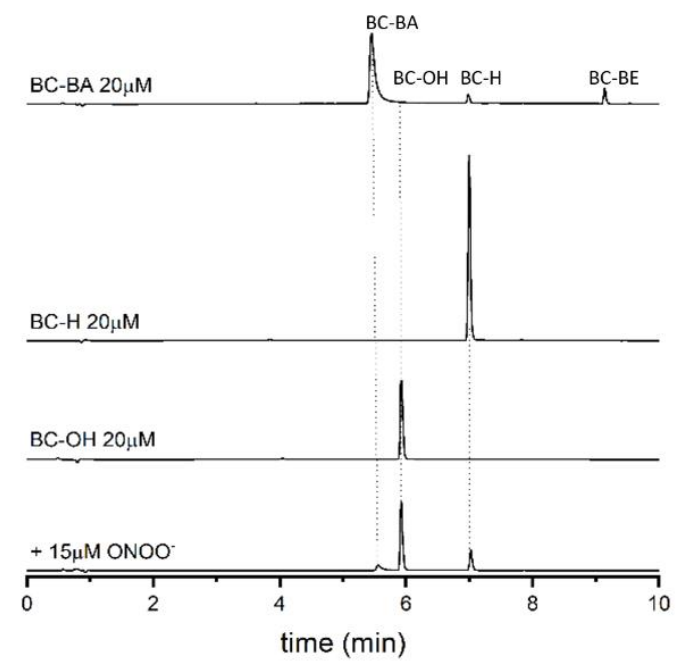

(a)

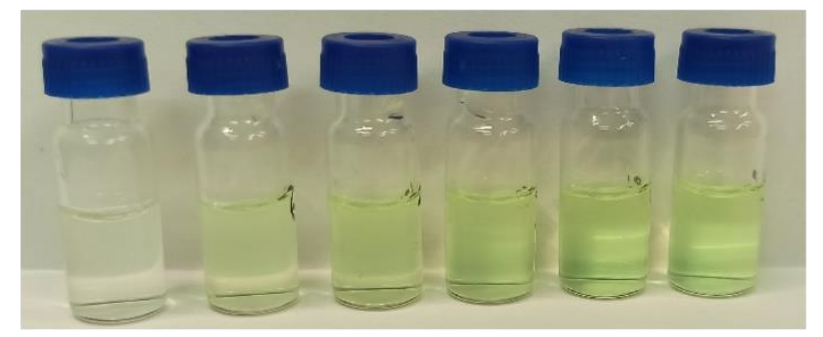

(c)

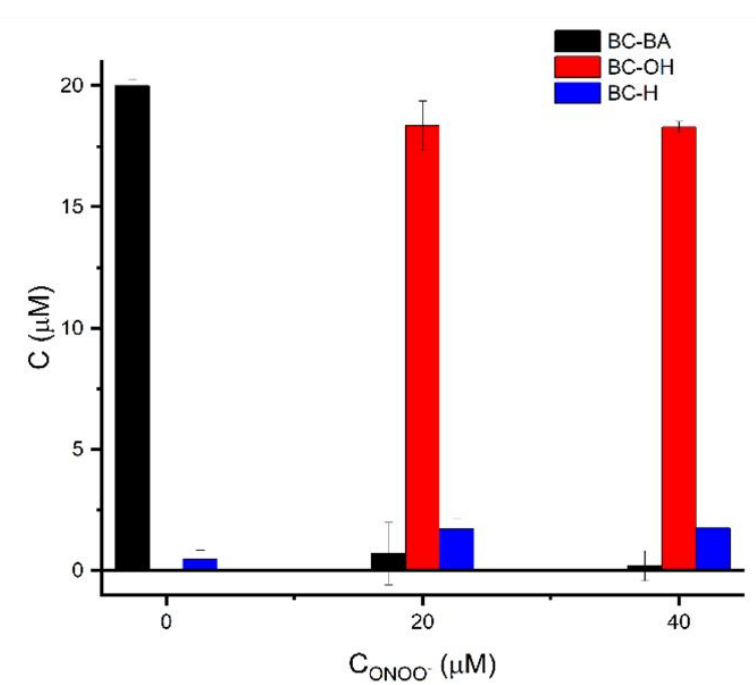

(b)

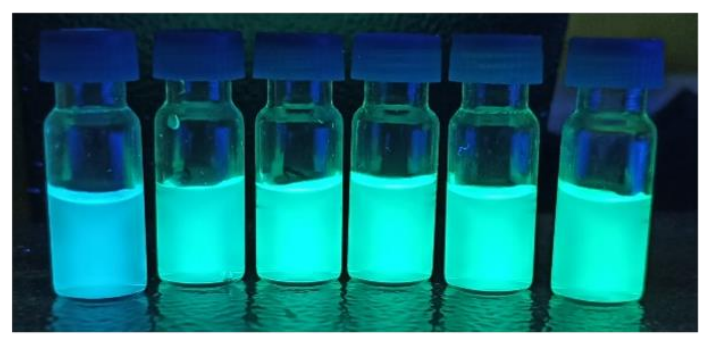

(d)

Figure 3. Peroxynitrite-induced oxidation of the BC-BA probe. (a) HPLC traces of the mixture of $\mathbf{B C}-\mathbf{B A}, \mathbf{B C}-\mathbf{O H}$, and BC-H $(20 \mu \mathrm{M}$ each) and the reaction mixtures of BC-BA $(20 \mu \mathrm{M})$ with peroxynitrite $(15 \mu \mathrm{M})$ after 5 min of incubation. Tests were conducted in aqueous solutions containing EtOH (10\%), phosphate buffer $(0.1 \mathrm{M}, \mathrm{pH} 7.4)$ and dtpa $(10 \mu \mathrm{M})$. The traces were collected using an absorption detector set at $330 \mathrm{~nm}$; (b) HPLC based titration of BC-BA probe (20 $\mu \mathrm{M})$ with ONOO$(0-40 \mu \mathrm{M})$. Pictures of BC-BA probe $(20 \mu \mathrm{M})$ with different amount of peroxynitrite $(0,6,12,18,24,30 \mu \mathrm{M})$ : (c) in day light; (d) under UV. 


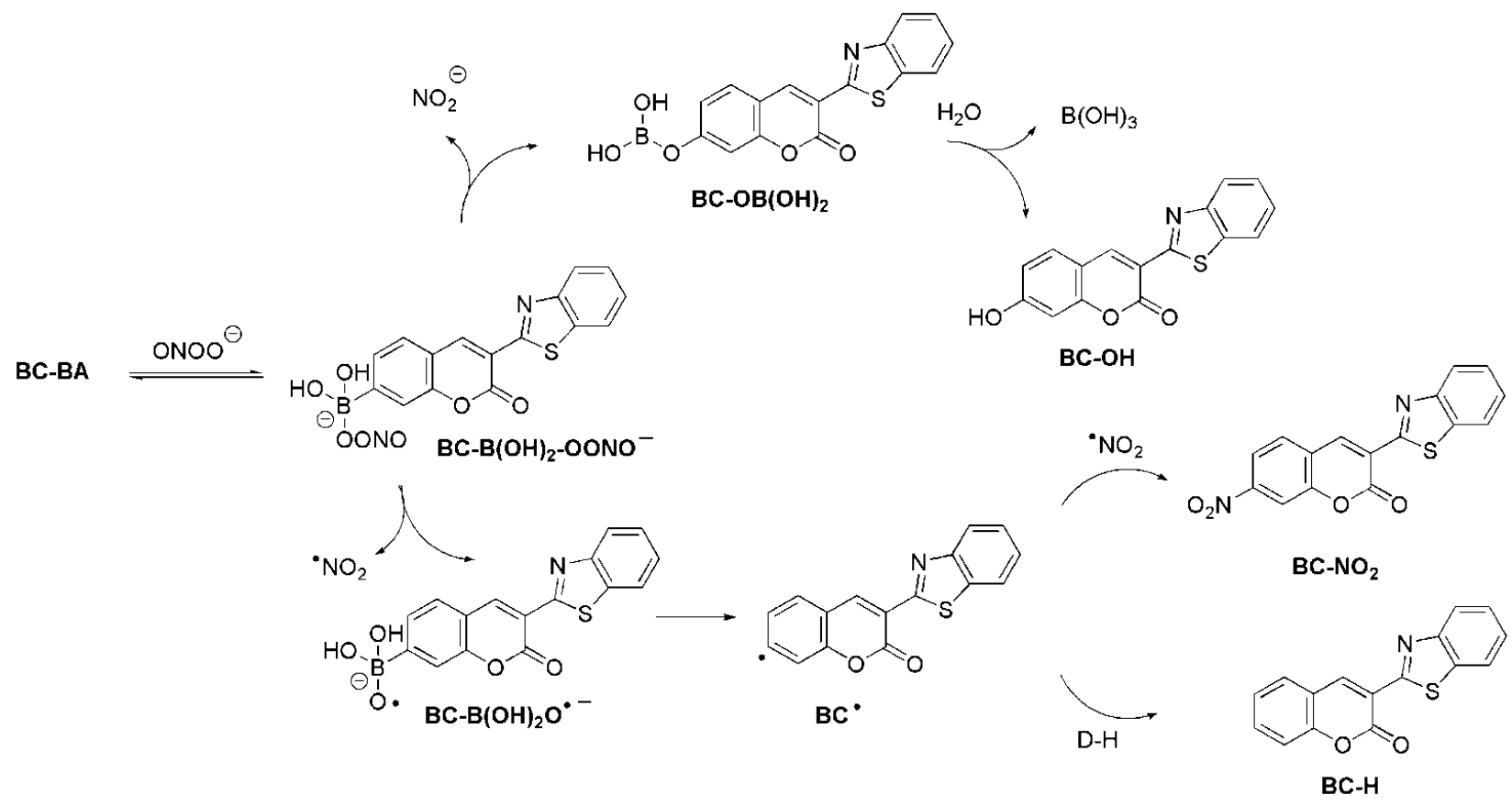

Scheme 3. Peroxynitrite induced oxidative conversion of BC-BA leading to benzothiazolyl-coumarin derived dyes BC-OH,

BC-H, and BC-NO .

Boronate probe is also oxidized by other inflammatory oxidants such as hydrogen peroxide and hypochlorous acid [27-30]. Therefore, we also tested the reactivity of BCBA toward $\mathrm{H}_{2} \mathrm{O}_{2}$ and $\mathrm{HOCl}$. We also compared the kinetic profile of $\mathbf{B C}-\mathbf{O H}$ formation during the oxidation of $\mathbf{B C}-\mathbf{B A}$ to the profile of the $\mathbf{C O H}$ formation from a simple boronate probe, coumarin-7-boronic acid (CBA). Figure 4a shows the buildup of emission at $442 \mathrm{~nm}$ during the reaction between those boronic probes and $\mathrm{H}_{2} \mathrm{O}_{2}(5 \mathrm{mM})$. It is evident that both probes release products (BC-OH or $\mathbf{C O H}$ ) with comparable reaction rates. However, the signal intensity of $\mathbf{B C - O H}$ is 3-fold higher than the signal emission of $\mathbf{C O H}$, demonstrating significantly higher brightness of the product, consistent with the fluorescence parameters listed in Table 1. It is also worth emphasizing that in the reaction of the BC-BA probe with $\mathrm{H}_{2} \mathrm{O}_{2}$, the $\mathbf{B C}-\mathbf{O H}$ coumarin is formed as the sole product (Figure $4 \mathrm{~b}$ ). [27-30].

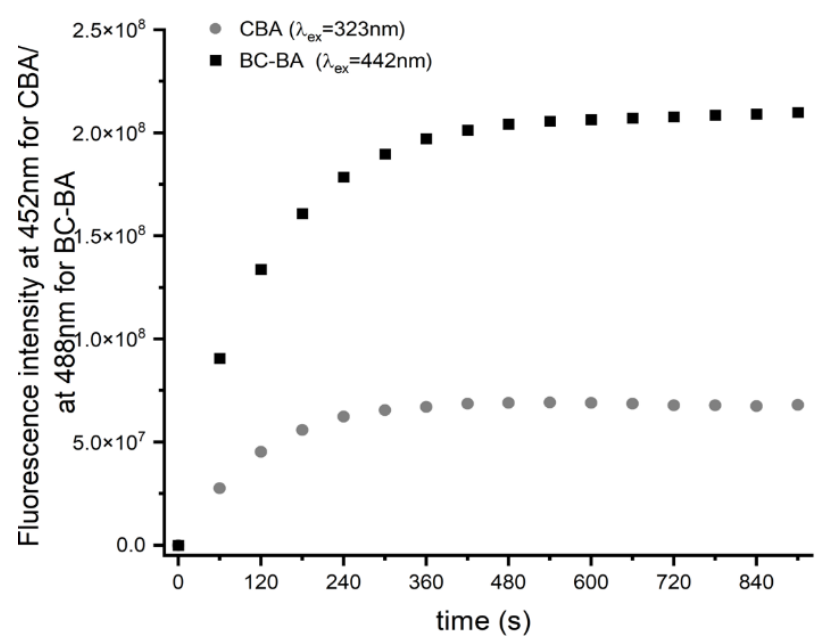

(a)

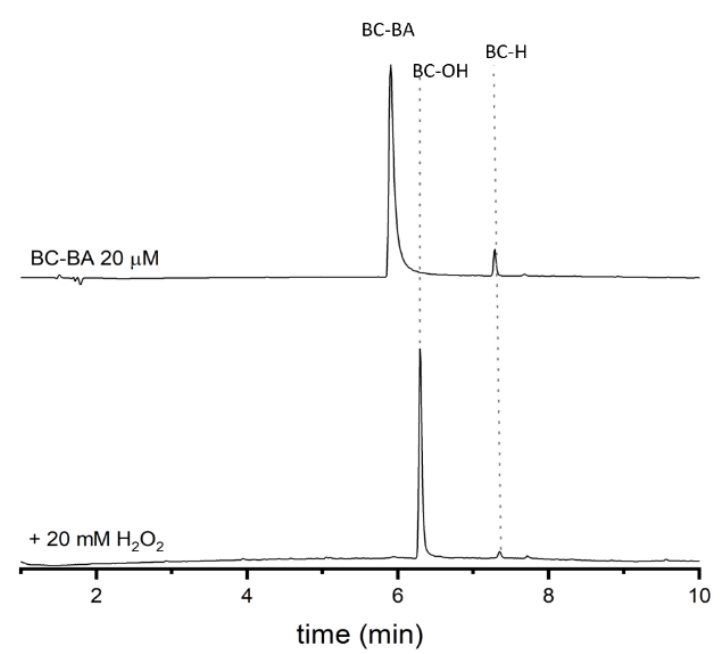

(b)

Figure 4. (a) Kinetic profiles of product formation during the oxidation of probes BC-BA and CBA $\left(5 \mu \mathrm{M}\right.$ each) by $\mathrm{H}_{2} \mathrm{O}_{2}$ $(5 \mathrm{mM})$. Experiments were repeated three times independently. Representative result displayed; (b) HPLC traces of the BC-BA probe $(20 \mu \mathrm{M})$ before and after addition of $\mathrm{H}_{2} \mathrm{O}_{2}(20 \mathrm{mM})$. 
Emission spectra recorded after the addition of a micromolar concentration of $\mathrm{H}_{2} \mathrm{O}_{2}$ into the phosphate buffer solution containing BC-BA are shown in Figure 5a. The intensity of recorded spectra are lower in comparison with the intensity of fluorescence measured after the reaction of $\mathbf{B C}-\mathbf{B A}$ with $\mathrm{ONOO}^{-}$(Figure 1d). For comparison, we also studied the reaction of BC-BA with hypochlorous acid. Emission spectra (Figure $5 b$ ) reveal that the BC-BA probe is converted to the $\mathbf{B C}-\mathbf{O H}$ dye. In contrast to the reaction of the probe with hydrogen peroxide, however, the signal intensity is significantly higher. HPLC analysis of the reaction mixture (Figure 6a) shows that besides $\mathbf{B C}-\mathbf{O H}$, another product is also formed. We attributed this product to the chlorinated derivative of the coumarin $\mathrm{BC}-\mathrm{OH}(\mathrm{Cl})$ since the product with the same retention time $(6.1 \mathrm{~min})$ was also detected after the addition of $\mathrm{HOCl}$ to the $\mathbf{B C}-\mathbf{O H}$ solution. By analyzing the disappearance of the BC-BA probe and the concentration of products formed with an increase in the amount of added $\mathrm{HOCl}$, it can be seen that the maximum yield of $\mathbf{B C}-\mathbf{O H}$ reaches only ca. $25 \%$. Moreover, an excess of $\mathrm{HOCl}$ causes the disappearance of $\mathbf{B C}-\mathbf{O H}$. This is consistent with our previous investigations in which we demonstrated that the phenolic product (luciferin or 6-(2-benzothiazolyl)2-naphthalenol) released from the boronate probes (LBA, PCL-1 or NAB-BE) undergoes a further reaction with $\mathrm{HOCl}$, leading to the formation of $7^{\prime}$-chloroluciferin $[27,28]$ or 6-(1,3-benzothiazol-2-yl)-1-chloronaphthalen-2-ol [29], a product specific for $\mathrm{HOCl}$.

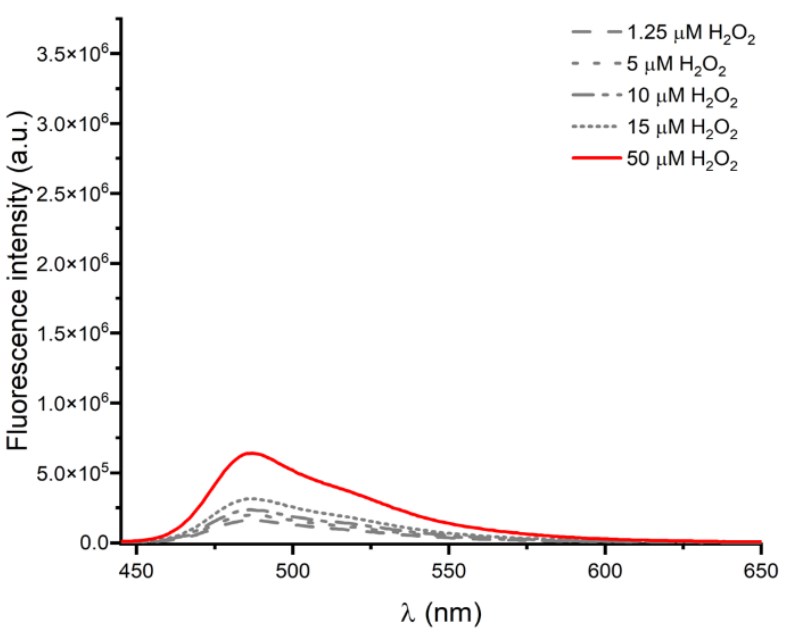

(a)

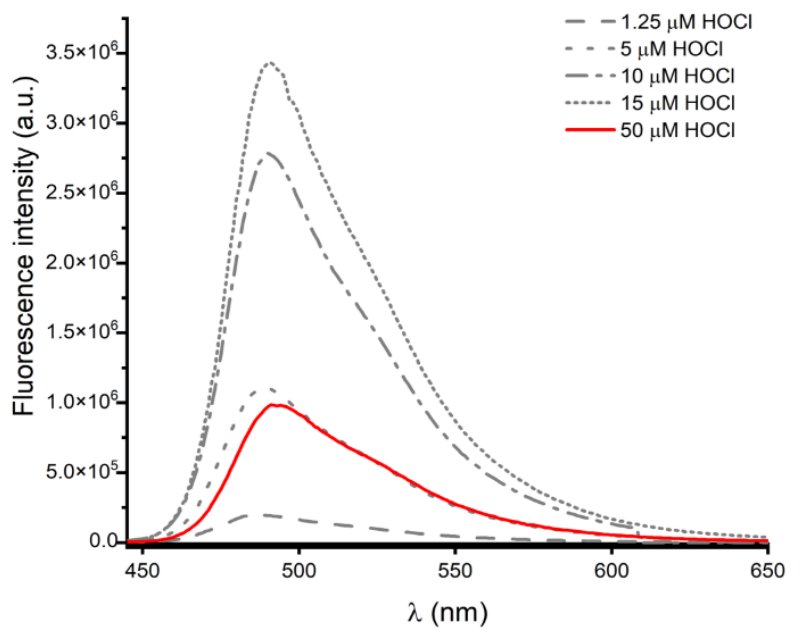

(b)

Figure 5. Emission spectra of the BC-BE probe $\left(5 \mu \mathrm{M}, \lambda_{\mathrm{ex}}=442 \mathrm{~nm}\right)$ recorded before and after bolus addition of different amount $(0,1.5,4.5,6,7.5 \mu \mathrm{M})$ of: (a) $\mathrm{H}_{2} \mathrm{O}_{2}$ (after $24 \mathrm{~h}$ of incubation); (b) $\mathrm{HOCl}$ (after 30 min of incubation). Tests were conducted in aqueous solutions containing EtOH (10\%), phosphate buffer (0.1 M, pH 7.4) and dtpa (10 $\mu \mathrm{M})$.

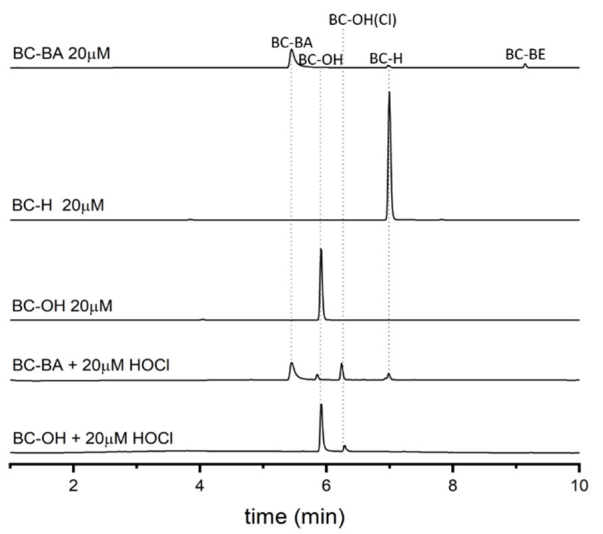

(a)

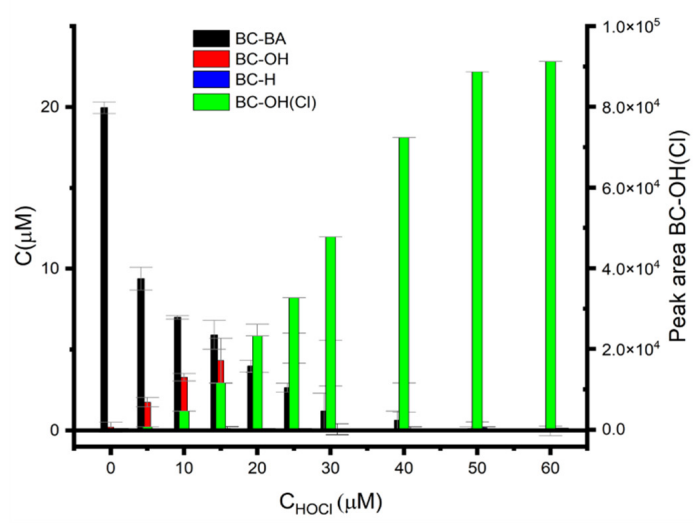

(b)

Figure 6. Cont. 


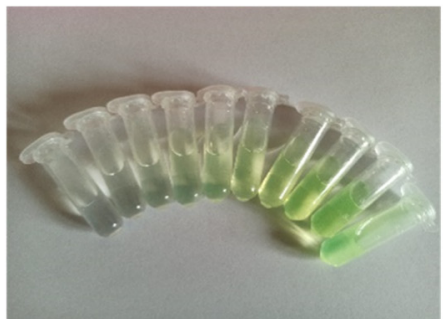

(c)

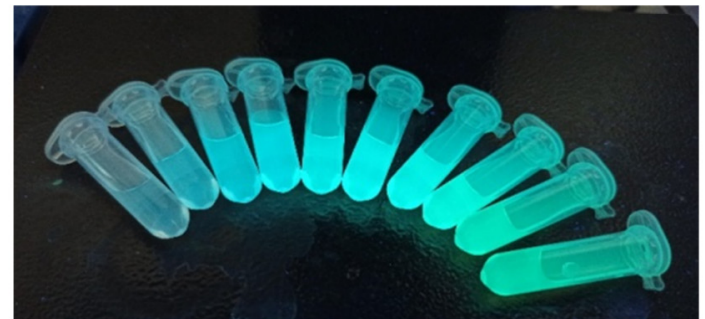

(d)

Figure 6. HOCl-induced oxidation of the BC-BA probe. (a) HPLC traces of the mixture of BC-BA, BC-OH and BC-H $(20 \mu \mathrm{M}$ each) and the reaction mixtures of BC-BA $(20 \mu \mathrm{M})$ and $\mathbf{B C}-\mathbf{O H}(20 \mu \mathrm{M})$ with $\mathrm{HOCl}(20 \mu \mathrm{M})$ after 15 min of incubation. Tests were conducted in aqueous solutions containing EtOH (10\%), phosphate buffer $(0.1 \mathrm{M}, \mathrm{pH} 7.4)$ and dtpa $(10 \mu \mathrm{M})$. The traces were collected using an absorption detector set at $330 \mathrm{~nm}$; (b) HPLC based titration of the BC-BA probe $(20 \mu \mathrm{M})$ with $\mathrm{HOCl}$ $(0-60 \mu \mathrm{M})$. Pictures of the BC-BE probe $(20 \mu \mathrm{M})$ with different amount of $\mathrm{HOCl}(0-60 \mu \mathrm{M})$ : (c) in day light; (d) under UV.

\subsection{The Effect of Compounds on Cell Metabolic Activity}

To determine the potential usage of synthesized compounds in cell-based assays, next the impact of probes on the metabolic activity of human colon cancer HT29 cells was studied. Compounds were dissolved in ethanol/dimethylsulfoxide mixture (9:1) and added to the cells in a volume not exceeding $2 \%$ of the medium, which had no cytotoxic effect on cells. To determine the cytotoxic potential of studied compounds, cells were incubated for $8 \mathrm{~h}$ in their presence at the range of $0-200 \mu \mathrm{M}$ concentration. As it is presented in Figure $7 \mathrm{a}-\mathrm{c}$, compounds BC-OH and BC-BA at $20 \mu \mathrm{M}$ concentration had no impact on HT29 cells' metabolic activity; therefore, both of them can be potentially used in studies requiring cell incubation for at least $20 \mathrm{~min}$. The direct comparison of cytotoxic potential within the studied range of concentration revealed that compound $\mathbf{B C}-\mathbf{O H}$ was more cytotoxic than BC-BA. The highest cytotoxicity of BC-OH was detected for $200 \mu \mathrm{M}$ with decreased metabolic activity by almost $20 \%$ compared to the control cells. Microscopic observations performed with calcein AM ester confirmed the lack of cytotoxic effects of both compounds at $20 \mu \mathrm{M}$ on HT29 cells, as shown in Figure 7d. In healthy cells with active esterases, there is a visible strong cytosolic green fluorescence of calcein. Cells incubated with $200 \mu \mathrm{M}$ of BC-OH had lower cytoplasmic esterase activity, thus a decreased green fluorescence of calcein was observed, as well as the presence of some less attached and more rounded cells.

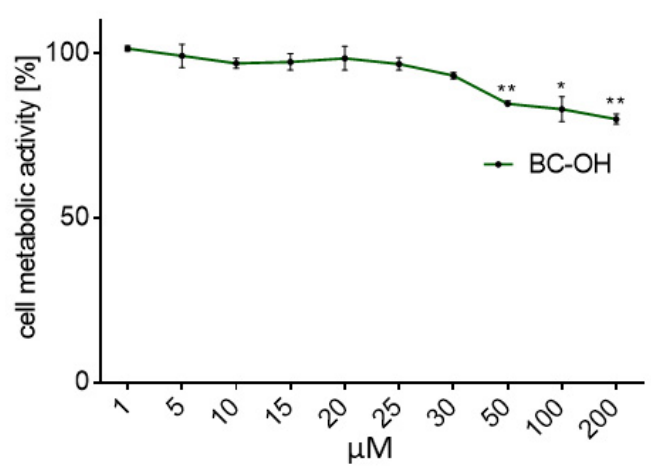

(a)

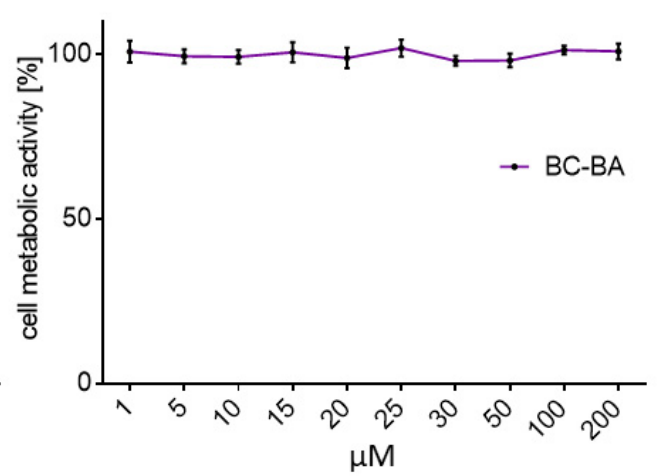

(b)

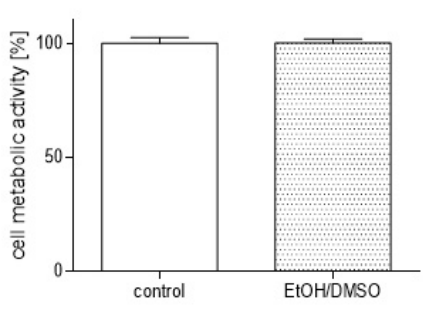

(c)

Figure 7. Cont. 

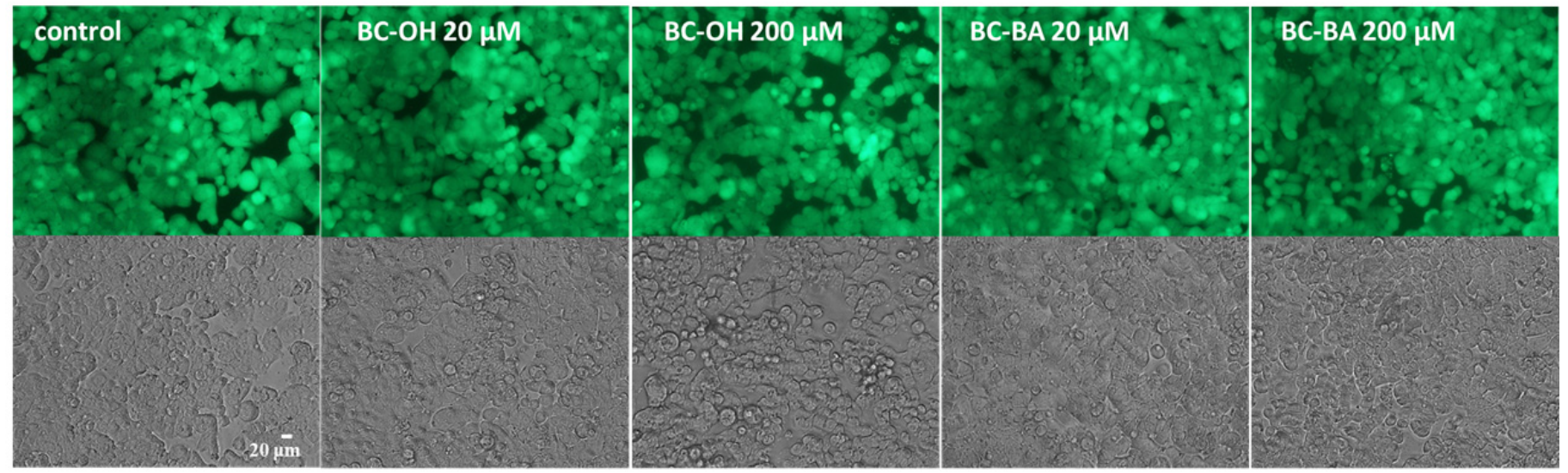

(d)

Figure 7. The influence of BC-OH (a) and BC-BA (b) on HT29 cell metabolic activity, determined by MTT assay after $8 \mathrm{~h}$ exposure; control cells were not exposed to any compound but the vehicle (EtOH/DMSO (9:1) (c); values are means \pm SEM, $n \geq 7$; statistical significance was calculated versus control cells (untreated), ${ }^{*} p \leq 0.05,{ }^{* *} p \leq 0.01$. Morphology of HT29 cells stained with $2 \mu \mathrm{M}$ calcein AM observed after incubation with 20 and $200 \mu \mathrm{M}$ of BC-OH and BC-BA (d); randomly chosen fields were photographed at $\times 200$ with fluorescent microscope Nikon TS Eclipse 100 .

\section{Materials and Methods}

\subsection{General}

The reagents used for the synthesis were commercially available. 3-benzothiazol-2-yl7-hydroxy-chromen-2-one (BC-OH) and 3-benzothiazol-2-yl-chromen-2-one (BC-H) were synthesized according to published protocols [32,38].

The purity of the final compounds was tested by HPLC (Shimadzu) equipped with a photodiode array detector and analytical column-Phenomenex Kinetex Core-Shell C18 $(100 \mathrm{~mm} \times 4.6 \mathrm{~mm} ; 2.6 \mu \mathrm{m})$. The mobile phase was a gradient prepared from acetonitrile with $0.1 \%$ of TFA (component A) and water with $0.1 \%$ of TFA (component $\mathrm{B}$ ). The analytes were eluted by an increase of A concentration from $10-100 \%$ over $10 \mathrm{~min}$ at the flow rate of $1.5 \mathrm{~mL} / \mathrm{min}$. The column temperature was set at $30^{\circ} \mathrm{C}$.

${ }^{1} \mathrm{H}$ NMR spectra were recorded with a Bruker Avance DPX 250 spectrometer at 250 $\mathrm{MHz}$, respectively (see Supplementary materials). Compounds were dissolved in DMSO$\mathrm{d}_{6}$ and TMS was added as internal reference. Mass spectra [TOF MS (ESI+)] were recorded on a Synapt G2-Si spectrometer (Waters, Milford, MA, USA).

Absorption spectra were recorded on UV-Vis-NIR spectrophotometer Jasco-V670. Steady-state and time-resolved fluorescence spectra were recorded on Edinburgh Analytical Instruments FL900.

BC-OH: ${ }^{1} \mathrm{H}$ NMR $\left(250 \mathrm{MHz}\right.$, DMSO- $\left.d_{6}\right): \delta 11.06(\mathrm{bs}, 1 \mathrm{H}), 9.16(\mathrm{~s}, 1 \mathrm{H}), 8.16(\mathrm{~d}$, $J=7.7 \mathrm{~Hz}, 1 \mathrm{H}), 8.05(\mathrm{~d}, J=8.1 \mathrm{~Hz}, 1 \mathrm{H}), 7.92(\mathrm{~d}, J=8.6 \mathrm{~Hz}, 1 \mathrm{H}), 7.57(\mathrm{t}, J=7.6 \mathrm{~Hz}, 1 \mathrm{H}), 7.46$ $(\mathrm{t}, J=7.5 \mathrm{~Hz}, 1 \mathrm{H}), 6.93(\mathrm{dd}, J=8.6,2.2 \mathrm{~Hz}, 1 \mathrm{H}), 6.86(\mathrm{~d}, J=2.1 \mathrm{~Hz}, 1 \mathrm{H})$. TOF MS ES+ calcd for $\mathrm{C}_{16} \mathrm{H}_{10} \mathrm{NO}_{3} \mathrm{~S} 296.0381$, found 296.0390. m.p. 303-305 ${ }^{\circ} \mathrm{C}$, lit. 302-304 ${ }^{\circ} \mathrm{C}$ [39].

BC-H: ${ }^{1} \mathrm{H}$ NMR $\left(250 \mathrm{MHz}\right.$, DMSO- $\left.d_{6}\right): \delta 9.06(\mathrm{~s}, 1 \mathrm{H}), 8.07(\mathrm{~d}, J=8.1,1 \mathrm{H}), 7.96(\mathrm{~d}$, $J=8.0,1 \mathrm{H}), 7.71(\mathrm{dd}, J=7.7,1.6 \mathrm{~Hz}, 1 \mathrm{H}), 7.6-7.59(\mathrm{~m}, 1 \mathrm{H}), 7.55-7.48(\mathrm{~m}, 1 \mathrm{H}), 7.44-7.33(\mathrm{~m}$, $3 \mathrm{H}$ ). TOF MS ES+ calcd for $\mathrm{C}_{16} \mathrm{H}_{10} \mathrm{NO}_{2} \mathrm{~S} 280.0432$, found 280.0439. m.p. 213-215 ${ }^{\circ} \mathrm{C}$, lit. $213-215^{\circ} \mathrm{C}[40]$.

\subsection{Synthesis of 3-(Benzo[d]thiazol-2-yl)-2-oxo-2H-chromen-7-yl Trifluoromethanesulfonate (BC-OTf)}

3-benzothiazol-2-yl-7-hydroxycoumarin BC-OH (148 mg, $0.5 \mathrm{mmol}$ ) and N-phenylbis(trifluoromethanesulfonimide) $(214 \mathrm{mg}, 0.6 \mathrm{mmol}$ ) were dissolved in $10 \mathrm{~mL}$ of anhydrous chloroform. Triethylamine $(0.36 \mathrm{~mL}, 2.6 \mathrm{mmol})$ was added to the mixture and the resulting solution was stirred under reflux for $4 \mathrm{~h}$. After cooling to room temperature, it was diluted 
with chloroform and washed three times with citric acid $(20 \%, 10 \mathrm{~mL})$, three times with water $(10 \mathrm{~mL})$, and three times with saturated solution $\mathrm{NaHCO}_{3}(10 \mathrm{~mL})$. The organic layer was dried over $\mathrm{MgSO}_{4}$ and the solvent was removed by rotary evaporation to give a yellowish solid (211 $\mathrm{mg}, 99 \%)$.

BC-OTf: ${ }^{1} \mathrm{H}$ NMR $\left(250 \mathrm{MHz}, \mathrm{DMSO}-d_{6}\right): \delta 9.26(\mathrm{~s}, 1 \mathrm{H}), 8.26(\mathrm{~d}, J=8.8 \mathrm{~Hz}, 1 \mathrm{H}), 8.18$ $(\mathrm{d}, J=7.7 \mathrm{~Hz}, 1 \mathrm{H}), 8.08(\mathrm{~d}, J=7.8 \mathrm{~Hz}, 1 \mathrm{H}), 7.90(\mathrm{~d}, J=2.4 \mathrm{~Hz}, 1 \mathrm{H}), 7.64-7.54(\mathrm{~m}, 2 \mathrm{H}), 7.47(\mathrm{t}$, $1 \mathrm{H})$. TOF MS ES+ calcd for $\mathrm{C}_{17} \mathrm{H}_{9} \mathrm{NO}_{5} \mathrm{~S}_{2} \mathrm{~F}_{3} 427.9874$, found 427.9876 . m.p. 167-170 ${ }^{\circ} \mathrm{C}$.

\subsection{Synthesis of 3-(2-Benzothiazolyl)-7-coumarin Boronic Acid Pinacol Ester (BC-BE)}

3-benzothiazol-2-yl-7-trifluoromethanesulfonate coumarin BC-OTf (43 mg, $0.1 \mathrm{mmol})$, bis(pinacolato)diboron (28 mg, $0.11 \mathrm{mmol}), \mathrm{Pd}(\mathrm{dppf}) \mathrm{Cl}_{2}(2.2 \mathrm{mg}, 0.003 \mathrm{mmol}), \mathrm{dppf}(1.7 \mathrm{mg}$, $0.003 \mathrm{mmol})$, and potassium acetate $(29 \mathrm{mg}, 0.3 \mathrm{mmol}$ ) were dissolved in $5 \mathrm{~mL}$ of anhydrous 1,4-dioxane. The reaction was heated in a microwave at $100{ }^{\circ} \mathrm{C}$ for $45 \mathrm{~min}$ under argon. After cooling to room temperature, the mixture was diluted with toluene and washed three times with brine. The organic layer was dried over $\mathrm{MgSO}_{4}$ and the solvent was removed by rotary evaporation to give a brown residue. The residue was purified with column chromatography (eluent DCM:MeOH; $19: 1 ; v / v)$ to give a beige solid (41 $\mathrm{mg}, 73 \%$ ).

BC-BE: ${ }^{1} \mathrm{H}$ NMR $\left(250 \mathrm{MHz}, \mathrm{DMSO}-d_{6}\right): \delta 9.24(\mathrm{~s}, 1 \mathrm{H}), 8.18(\mathrm{~d}, J=6.7 \mathrm{~Hz}, 1 \mathrm{H}), 8.07(\mathrm{t}$, $J=7.7 \mathrm{~Hz}, 2 \mathrm{H}), 7.93(\mathrm{~s}, 1 \mathrm{H}), 7.72-7.53(\mathrm{~m}, 1 \mathrm{H}), 7.47(\mathrm{t}, J=7.5 \mathrm{~Hz}, 1 \mathrm{H}), 7.17(\mathrm{~d}, J=8.2 \mathrm{~Hz}$, $1 \mathrm{H}), 1.31(\mathrm{~s}, 12 \mathrm{H})$. TOF MS ES+ calcd for $\mathrm{C}_{22} \mathrm{H}_{21} \mathrm{NO}_{4} \mathrm{SB} 406.1284$, found 406.1288. m.p. $229-233{ }^{\circ} \mathrm{C}$.

\subsection{Real-Time Monitoring of Oxidation BC-BE Boronic Probe in Cell-Free System Generating $-\mathrm{NO}$ and $\mathrm{O}_{2}^{\bullet-}$}

All solutions were prepared using deionized water (Millipore Milli-Q system). Due to poor solubility of probes in water, all experiments were performed with addition of an up $1 \%(v / v)$ of DMSO. The profiles of $\mathrm{ONOO}^{-}$formation in a solution with hypoxanthine (HX) and xanthine oxidase $(\mathrm{XO})$ as a source of steady flux of superoxide $\mathrm{O}_{2}{ }^{\bullet-}$ and spermineNONOate as a source of $\bullet$ NO, were monitored using BC-BA as fluorogenic probe. The total fluorescence intensity of formed $\mathbf{B C}-\mathbf{O H}$ dye was measured using a Beckman Coulter DTX880 plate reader. The instrument was kept at $37{ }^{\circ} \mathrm{C}$ during the measurements. The changes in fluorescence intensity were monitored over a $2 \mathrm{~h}$ period. ${ }^{\bullet} \mathrm{NO}$ fluxes were determined from the rate of decomposition of spermine-NONOate measured by following the decrease of its characteristic absorbance at $252 \mathrm{~nm}\left(\varepsilon=8.5 \times 10^{3} \mathrm{M}^{-1} \mathrm{~cm}^{-1}\right)$ [41]. The flux of $\mathrm{O}_{2}{ }^{\bullet-}$ was determined by monitoring the cytochrome $\mathrm{c}\left(\mathrm{Fe}^{3+}\right)$ reduction and the increase in absorbance at $550 \mathrm{~nm}$ (using a difference in the values of the extinction coefficients between reduced and oxidized cytochrome of $2.1 \times 10^{4} \mathrm{M}^{-1} \mathrm{~cm}^{-1}$ ). In our experiments peroxynitrite was co-generated from fluxes of $\mathrm{O}_{2}{ }^{\bullet-}$ and ${ }^{\bullet} \mathrm{NO}$ in the phosphate buffer (pH 7.4, $50 \mathrm{mM})$ with DTPA $(100 \mu \mathrm{M}), \mathrm{HX} / \mathrm{XO}(1 \mathrm{mM} / 70 \mu \mathrm{U} / \mathrm{mL})$, spermineNONOate $(75 \mu \mathrm{M})$ and CAT $(100 \mathrm{U} / \mathrm{mL})$. Such systems produced up to $0.2 \mu \mathrm{M} / \mathrm{min}$ flux of peroxynitrite.

\subsection{Cell Culture and Exposure Conditions}

Human colon carcinoma cell line HT29 was obtained from ATCC, (Manassas, VA, USA). Cells were grown in DMEM with a $10 \%$ fetal bovine serum (FBS) medium supplemented with $100 \mathrm{U} / \mathrm{mL}$ penicillin, $100 \mu \mathrm{g} / \mathrm{mL}$ streptomycin, and $25 \mu \mathrm{g} / \mathrm{mL}$ amphotericin B. All cell culture experiments were performed in a humidified $5 \% \mathrm{CO}_{2}$ and $95 \%$ atmosphere at $37^{\circ} \mathrm{C}$. All cell culture reagents were obtained from Life Technologies (Carlsbad, CA, USA).

\subsection{Cell Metabolic Activity}

Metabolic activity was evaluated with MTT assay. Briefly, cells were seeded into 96well plate at $1 \times 10^{4}$ cells/well density in $100 \mu \mathrm{L}$ complete medium and grown overnight, and then incubated in the presence of studied compounds for another $8 \mathrm{~h}$. After this, $20 \mu \mathrm{L}$ of MTT reagent ( $5 \mathrm{mg} / \mathrm{mL}$ ) was added for $120 \mathrm{~min}$. After that time, MTT was removed, 
and formazan precipitates were solubilized by adding $100 \mu \mathrm{L}$ of DMSO. Absorbance was measured at $570 \mathrm{~nm}$ using the Synergy 2 BioTek Microplate Reader (BioTek, Winooski, VT, USA).

\section{Conclusions}

We used 3-benzothiazol-2-yl-7-hydroxy-chromen-2-one fluorophore to develop a novel boronate probe for the selected biological oxidants. The BC-BA probe showed similar reactivity toward selected inflammatory oxidants to the previously reported CBA probe [17], producing fluorescent BC-OH phenolic product. In comparison to CBA, BC-BA is significantly more lipophilic, which may improve its cellular uptake. Furthermore, the fluorescence of the oxidation product is red shifted and its brightness is ca. 3-fold higher. This may help in the successful application of the probe for the imaging of biological oxidants in cultured cells. Detection of the minor products characteristic for a specific oxidant $\left(\mathrm{ONOO}^{-}\right.$or $\left.\mathrm{HOCl}\right)$ will allow the unambiguous identification of the oxidants involved in probe oxidation.

Further structure modifications may be introduced to the developed scaffold to modulate the water solubility of the probe, fluorescence properties of the probe and the product and to target the probe to specific subcellular or extracellular compartments.

Supplementary Materials: The following are available online. Figure S1: HPLC chromatograms of the BC-BA in aqueous solution containing phosphate buffer $(0.1 \mathrm{M}, \mathrm{pH} 7.4)$, dtpa $(10 \mu \mathrm{M})$ and $\mathrm{EtOH}(10 \%)$ : freshly made solution (above), after $10 \mathrm{~min}$ (below). The traces were collected using the absorption detector set at $330 \mathrm{~nm}$, Figure S2: ${ }^{1} \mathrm{H}$ NMR spectrum of BC-OH in $d_{6}$-DMSO, Figure S3: ${ }^{1} \mathrm{H}$ NMR spectrum of BC-H in $\mathrm{CDCl}_{3}$, Figure S4: ${ }^{1} \mathrm{H}$ NMR spectrum of BC-OTf in $d_{6}$-DMSO, Figure S5: ${ }^{1} \mathrm{H}$ NMR spectrum of BC-BE in $d_{6}$-DMSO, Figure S6: Mass spectrum of BC-OH, Figure S7: Mass spectrum of BC-H, Figure S8: Mass spectrum of BC-OTf, Figure S9: Mass spectrum of BC-BE.

Author Contributions: Conceptualization, J.Z. and R.P.; methodology, J.M.; validation, J.M., M.S., M.Z.-S. and A.G.; formal analysis, J.M.; investigation, J.M. and M.Z.-S.; resources, J.M.; data curation, J.M.; writing—original draft preparation, J.M.; writing—review and editing, R.P. and J.Z.; visualization, J.M.; supervision, R.P. and J.Z.; project administration, R.P. and J.Z.; funding acquisition, J.Z. and R.P. All authors have read and agreed to the published version of the manuscript.

Funding: This research was funded by a grant from the Polish National Science Centre within the SONATA BIS 6 program (Grant no. 2016/22/E/ST4/00549) to R.P. J.Z. was supported in part by the Institutional Research Grant IRG \#16-183-31 from the American Cancer Society and the MCW Cancer Center.

Institutional Review Board Statement: Not applicable.

Informed Consent Statement: Not applicable.

Data Availability Statement: The data presented in this study are available in article and supplementary material.

Conflicts of Interest: The authors declare no conflict of interest.

Sample Availability: Samples of the compounds BC-BA, BC-OH, and BC-H are available from the authors.

\section{References}

1. Cao, D.; Liu, Z.; Verwilst, P.; Koo, S.; Jangjili, P.; Kim, J.S.; Lin, W. Coumarin-based small-molecule fluorescent chemosensors. Chem. Rev. 2019, 119, 10403-10519. [CrossRef]

2. The Colour Index ${ }^{\mathrm{TM}}$. Available online: https:/ / colour-index.com/ (accessed on 10 April 2021).

3. Sokołowska, J.; Czajkowski, W.; Podsiadły, R. The photostability of some fluorescent disperse dyes derivatives of coumarin. Dye. Pigment. 2001, 49, 187-191. [CrossRef]

4. Telange, D.R.; Nirgulkar, S.B.; Umekar, M.J.; Patil, A.T.; Pethe, A.M.; Bali, N.R. Enhanced transdermal permeation and antiinflammatory potential of phospholipids complex-loaded matrix film of umbelliferone: Formulation development, physicochemical and functional characterization. Eur. J. Pharm. Sci. 2019, 131, 23-38. [CrossRef]

5. Mahoney, K.M.; Goswami, P.P.; Winter, A.H. Self-immolative aryl phthalate esters. J. Org. Chem. 2013, 78, 702-705. [CrossRef] 
6. Li, L.; Zhang, M.; Chang, K.; Kang, Y.; Ren, G.; Hou, X.; Liu, W.; Wang, H.; Wang, B.; Diao, H. A novel fluorescent off-on probe for the sensitive and selective detection of fluoride ions. RSC Adv. 2019, 9, 32308-32312. [CrossRef]

7. Salahuddin, S.; Renaudet, O.; Reymond, J.-L. Aldehyde detection by chromogenic/fluorogenic oxime bond fragmentation. Org. Biomol. Chem. 2004, 2, 1471-1475. [CrossRef]

8. $\mathrm{Gu}, \mathrm{X} . ; \mathrm{Zhu}, \mathrm{H}$; Yang, S.; Zhu, Y.-C.; Zhu, Y.-Z. Development of a highly selective $\mathrm{H}_{2} \mathrm{~S}$ fluorescent probe and its application to evaluate CSE inhibitors. RSC Adv. 2014, 4, 50097-50101. [CrossRef]

9. Bae, J.; Choi, J.; Park, T.J.; Chang, S.-K. Reaction-based colorimetric and fluorogenic signaling of hydrogen sulfide using a 7-nitro-2,1,3-benzoxadiazole-coumarin conjugate. Tetrahedron Lett. 2014, 55, 1171-1174. [CrossRef]

10. Wang, L.; Li, W.; Zhi, W.; Ye, D.; Wang, Y.; Ni, L.; Bao, X. A rapid-responsive fluorescent probe based on coumarin for selective sensing of sulfite in aqueous solution and its bioimaging by turn-on fluorescence signal. Dye Pigments 2017, 147, 357-363. [CrossRef]

11. Zhang, D.; Chen, W.; Kang, J.; Ye, Y.; Zhao, Y.; Xian, M. Highly selective fluorescence off-on probes for biothiols and imaging in live cells. Org. Biomol. Chem. 2014, 12, 6837-6841. [CrossRef] [PubMed]

12. Sun, W.; Li, J.; Li, W.H.; Su, L.J.; Du, L.P.; Li, M.Y. Design of OFF/ON fluorescent thiol probes based on coumarin fluorophore. Sci. China Chem. 2012, 55, 1776-1780. [CrossRef]

13. Badalassi, F.; Wahler, D.; Klein, G.; Crotti, P.; Reymond, L.-J. A versatile periodate-coupled fluorogenic assay for hydrolytic enzymes. Angew. Chem. Int. Ed. 2000, 39, 4067-4070. [CrossRef]

14. Nyfeler, E.; Grognux, J.; Wahler, D.; Reymond, J.-L. A sensitive and selective high-throughput screening fluorescence assay for lipases and esterases. Helv. Chim Acta 2003, 86, 2919-2927. [CrossRef]

15. Xue, F.; Seto, C.T. Fluorogenic peptide substrates for serine and threonine phosphatases. Org. Lett. 2010, 12, 1936-1939. [CrossRef]

16. Chen, W.; Liu, C.; Peng, B.; Zhao, Y.; Pacheco, A.; Xian, M. New fluorescent probes for sulfane sulfurs and the application in bioimaging. Chem. Sci. 2013, 4, 2892-2896. [CrossRef]

17. Zielonka, J.; Sikora, A.; Joseph, J.; Kalyanaraman, B. Peroxynitrite is the major species formed from different flux ratios of co-generated nitric oxide and superoxide. J. Biol. Chem. 2010, 285, 14210-14216. [CrossRef]

18. Zielonka, J.; Zielonka, M.; Verplank, L.; Cheng, G.; Hardy, M.; Ouari, O.; Ayhan, M.M.; Podsiadły, R.; Sikora, A.; Lambeth, D.J.; et al. Mitigation of NADPH oxidase 2 activity as a strategy to inhibit peroxynitrite formation. J. Biol. Chem. 2016, 291, 7029-7044. [CrossRef]

19. Wang, H.; Li, W.-G.; Zeng, K.; Wu, Y.-J.; Zhang, Y.; Xu, T.-L.; Chen, Y. Photocatalysis Enables Visible-Light Uncaging of Bioactive Molecules in Live Cells. Angew. Chem. Int. Ed. 2019, 58, 561-565. [CrossRef] [PubMed]

20. Shaobing, Q.; Dongdong, D.; Chunlei, G.; Zhenglong, S.; Hui, L.; Xuhong, Q.; Youjun, Y. Amino-substituted C-coumarins: Synthesis, spectral characterizations and their applications in cell imaging. Dye Pigments 2019, 163, 55-61. [CrossRef]

21. Saczewski, J.; Hinc, K.; Obuchowski, M.; Gdaniec, M. The tandem Mannich-electrophilic amination reaction: A versatile platform for fluorescent probing and labeling. Chem. Eur. J. 2013, 19, 11531-11535. [CrossRef] [PubMed]

22. Tasior, M.; Kim, D.; Singha, S.; Krzeszewski, M.; Ahn, K.H.; Gryko, D.T. П-Expanded coumarins: Synthesis, optical properties and applications. J. Mater. Chem. C 2015, 3, 1421-1446. [CrossRef]

23. Wang, X.; Fang, H.; Huang, Z.; Shang, W.; Hou, T.; Cheng, A.; Cheng, H. Imaging ROS signaling in cells and animals. J. Mol. Med. 2013, 91, 917-927. [CrossRef] [PubMed]

24. Winterbourn, C.C. The challenges of using fluorescent probes to detect and quantify specific reactive oxygen species in living cells. Biochim. Biophys. Acta 2014, 1840, 730-738. [CrossRef] [PubMed]

25. Prolo, C.; Rios, N.; Piacenza, L.; Álvarez, M.N.; Radi, R. Fluorescence and chemiluminescence approaches for peroxynitrite detection. Free Radic. Biol. Med. 2018, 128, 59-68. [CrossRef] [PubMed]

26. Wardman, P. Fluorescent and luminescent probes for measurement of oxidative and nitrosative species in cells and tissues: Progress, pitfalls, and prospects. Free Radic. Biol. Med. 2007, 43, 995-1022. [CrossRef] [PubMed]

27. Zielonka, J.; Podsiadły, R.; Zielonka, M.; Hardy, M.; Kalyanaraman, B. On the use of peroxy-caged luciferin (PCL-1) probe for bioluminescent detection of inflammatory oxidants in vitro and in vivo-dentification of reaction intermediates and oxidantspecific minor products. Free Radic. Biol. Med. 2016, 99, 32-42. [CrossRef] [PubMed]

28. Szala, M.; Grzelakowska, A.; Modrzejewska, J.; Siarkiewicz, P.; Słowiński, D.; Świerczyńska, M.; Zielonka, J.; Podsiadły, R. Characterization of the reactivity of luciferin boronate-A probe for inflammatory oxidants with improved stability. Dye Pigments 2020, 183, 108693. [CrossRef]

29. Grzelakowska, A.; Zielonka, M.; Dębowska, K.; Modrzejewska, J.; Szala, M.; Sikora, A.; Zielonka, J.; Podsiadły, R. Two-photon fluorescent probe for cellular peroxynitrite: Fluorescence detection, imaging, and identification of peroxynitrite-specific products. Free Radic. Biol. Med. 2021, 169, 24-35. [CrossRef]

30. Sikora, A.; Zielonka, J.; Dębowska, K.; Michalski, R.; Smulik-Izydorczyk, R.; Pięta, J.; Podsiadły, R.; Artelska, A.; Pierzchała, K.; Kalyanaraman, B. Boronate-based probes for inflammatory oxidants-A novel class of molecular tools for redox biology. Front. Chem. 2020, 8, 843-875. [CrossRef]

31. Parvez, S.; Long, M.J.C.; Poganik, J.R.; Aye, Y. Redox signaling by reactive electrophiles and oxidants. Chem. Rev. 2018, 118, 8789-8888. [CrossRef] [PubMed] 
32. Khoobia, M.; Ramazania, A.; Foroumadib, A.R.; Hamadic, H.; Hojjatia, Z.; Shafieeb, A. Efficient microwave-assisted synthesis of 3-benzothiazolo and 3-benzothiazolino coumarin derivatives catalyzed by heteropoly acids. J. Iran. Chem. Soc. 2011, 8, 1036-1042. [CrossRef]

33. Garcia-Molina, M.; Munoz-Munoz, J.L.; Garcia-Molina, F.; Rodriguez-Lopez, J.N.; Garcia-Canovas, F. Study of umbelliferone hydroxylation to esculetin catalyzed by polyphenol oxidase. Biol. Pharm. Bull. 2013, 36, 1140-1145. [CrossRef]

34. Roubinet, B.; Chevalier, A.; Renard, P.-Y.; Romieu, A. A synthetic route to 3-(heteroaryl)-7-hydroxycoumarins designed for biosensing applications. Eur. J. Org. Chem. 2015, 1, 166-182. [CrossRef]

35. Tan, B.; Liu, L.; Zheng, H.; Cheng, T.; Zhu, D.; Yang, X.; Luan, X. Two-in-one strategy for fluorene-based spirocycles via $\operatorname{Pd}(0)$-catalyzed spiroannulation of o-iodobiaryls with bromonaphthols. Chem. Sci. 2020, 11, 10198-10203. [CrossRef] [PubMed]

36. Sikora, A.; Zielonka, J.; Lopez, M.; Dybala-Defratyka, A.; Joseph, J.; Marcinek, A.; Kalyanaraman, B. Reaction between peroxynitrite and boronates: EPR spin-trapping, HPLC Analyses, and quantum mechanical study of the free radical pathway. Chem. Res. Toxicol. 2011, 24, 687-697. [CrossRef]

37. Sikora, A.; Zielonka, J.; Adamus, J.; Debski, D.; Dybala-Defratyka, A.; Michalowski, B.; Joseph, J.; Hartley, R.C.; Murphy, M.P.; Kalyanaraman, B. Reaction between peroxynitrite and triphenylphosphonium-substituted arylboronic acid isomers: Identification of diagnostic marker products and biological implications. Chem. Res. Toxicol. 2013, 26, 856-867. [CrossRef]

38. Yang, J.; Yu, Y.; Wang, B.; Jiang, Y. A sensitive fluorescent probe based on coumarin for detection of cysteine in living cells. J. Photochem. Photobiol. A Chem. 2017, 338, 178-182. [CrossRef]

39. Wang, K.; Lai, G.; Li, Z.; Liu, M.; Shen, Y.; Wang, C. A novel colorimetric and fluorescent probe for the highly selective and sensitive detection of palladium based on $\mathrm{Pd}(0)$ mediated reaction. Tetrahedron 2015, 71, 7874-7878. [CrossRef]

40. Yu, T.C.; Zhang, Y.; Zhao, H.; Chai, W.; Li, A. one-pot reaction to synthesize two types of fluorescent materials containing benzothiazolyl moiety. Spectrochim. Acta A 2013, 108, 274-279. [CrossRef] [PubMed]

41. Maragos, C.M.; Morley, D.; Wink, D.A.; Dunams, T.M.; Saavedra, J.E.; Hoffman, A.; Bove, A.A.; Isaac, L.; Hrabie, J.A.; Keefer, L.K. Complexes of $\mathrm{NO}$ with nucleophiles as agents for the controlled biological release of nitric oxide. Vasorelaxant effects. J. Med. Chem. 1991, 34, 3242-3247. [CrossRef] 